\title{
Konsep Awal Islamic Corporate Governance: Peluang Penelitian yang Akan Datang
}

\author{
Hikmah Endraswati \\ Pascasarjana Universitas Sebelas Maret (UNS) Surakarta \\ E-mail: h endraswati@yahoo.co.id
}

\begin{abstract}
The purpose of this article is giving the basic concept of Islamic corporate governance with the four leadership principles namely shiddiq, amanah, tablig, and fathanah. Next research and exploration about the conceptual of Islamic corporate governance is very important to be done because this research is still rare. The opportunity for future researcher in this topic is discussed in this paper.
\end{abstract}

Keywords: Islam, Corporate Governance, Shiddiq, Amanah, Tabligh, Fathanah

\begin{abstract}
Abstrak
Tujuan dari artikel ini adalah untuk memberi konsep dasar mengenai Islamic Corporate Governance dengan menggunakan empat prinsip kepemimpinan yaitu, siddiq, amanah, tablig, dan fathanah. Penelitian ini masih tergolong langka sehingga konsep islam perlu dilakukan. Kesempatan bagi peneliti dimasa mendatang dalam topic ini dibahas dalam penelitian ini.
\end{abstract}

Kata kunci: Islam, Corporate Gorvencance, Shiddiq, Amanah, Tabilg, Fathanah

\section{Pendahuluan}

Kasus manipulasi laporan keuangan yang dilakukan oleh Perusahaan Enron pada tahun 2001 berupa pengungkapan laba perusahaan sebesar 600 juta Dollar AS telah merugikan investor saham. Hal ini merupakan contoh perilaku moral hazard dalam perusahaan karena pada kenyataannya 
Perusahaan Enron mengalami kerugian. Tujuan manipulasi laporan keuangan tersebut agar saham perusahaan diminati publik. Kasus ini menyeret perusahaan Akuntan Publik Arthur Andersen yang kemudian ditutup ijin operasionalnya (Hafikahadiyanti, 2013).

Kasus serupa di US menimpa Perusahaan Worldcom sebagai perusahaan komunikasi terbesar ke dua yang dinyatakan pailit pada tahun 2002 setelah terbukti melakukan manipulasi dalam laporan keuangannya. Perusahaan ini memanipulasi pendapatannya sebesar 3,8 Milliar Dollar US. Audit eksternal yang digunakan saat itu Arthur Andersen (Computesta.com, 2012).

Kasus serupa terjadi di Indonesia pada tahun yang sama yang dilakukan oleh PT Kimia Farma. PT Kima Farma merupakan salah satu perusahaan BUMN melaporkan laba perusahaan sebesar Rp. 132 Milyar pada 31 Desember 2001. Laporan keuangan tersebut diaudit oleh Hans Tuanakotta \& Mustofa (HTM). Kementerian BUMN dan Bapepem menyatakan adanya manipulasi laporan keuangan setelah dilakukan audit ulang (Kompasiana.com, 2015).

Pada dunia perbankan, kasus Bank Century di Indonesia yang mendapatkan dana penyelamatan sebesar Rp. 6,76 Trilyun dari Lembaga Penjamin Simpanan (LPS) telah merugikan keuangan Negara pada pendanaan jangka pendek. Bank Century mendapatkan dana penyelamatan setelah dikategorikan sebagai bank gagal (republika.co.id, 2014).

Kasus Bank Lippo yang memberikan laporan keuangan berbeda antara publik dan Bursa Efek Indonesia (BEI) merupakan kasus lain pada perbankan di Indonesia. Bank Lippo menyatakan bahwa per 30 September 2002 memiliki total aktiva sebesar Rp. 24 Triliun dan laba bersih Rp. 98 Miliar pada publik. Hal tersebut berbeda dengan yang disampaikan pada laporan BEI pada 27 Desember 2002 yang menyatakan bahwa Bank Lippo memiliki total aktiva sebesar Rp. 22,8 Triliun dan perusahaan merugi Rp. 1,3 triliun (suaramerdeka.com, 2003).

Kasus-kasus di atas bersumber pada praktik corporate governance yang buruk. Prinsip-prinsip corporate governance menurut Komite Nasional Kebijakan Governance (KNKG) tahun 2006 diantaranya adalah transparancy, accountability, responsibility, independence, dan fairness. Kasus-kasus 
tersebut lebih berkaitan dengan prinsip transparansi dalam corporate governance (Tjager, 2003). Dengan adanya kasus manipulasi pelaporan keuangan tersebut, prinsip transparansi, pengungkapan informasi dan peran akuntan dalam menghasilkan informasi keuangan mulai dipertanyakan. Ketidakjujuran dalam pengungkapan informasi akan menyebabkan investor, konsumen, supplier, masyarakat, dan pemerintah menjadi tidak percaya pada perusahaan, hilangnya potensi perusahaan untuk berkembang (area pemasaran, produk, produksi, penjualan, laba) dan hilangnya sumber penghasilan karyawan karena perusahaan menjadi bangkrut.

Karena pentingnya topik corporate governance ini, maka penelitianpenelitian tentang corporate governance dengan konsep konvensional telah banyak dilakukan di berbagai negara seperti Eropa, Amerika, Asia, Afrika, dan Australia. Beberapa peneliti tersebut seperti Donaldson dan Davis (1991) pada perusahaan yang terdaftar pada S\&P di US, Shleifer dan Vishny (1996) di US, Sullivan (1998) di Jerman, Laporta, Silanes dan Shleifer (1999) pada 27 negara dengan pendapatan terbesar, Emmons dan Schmid (1999) di US, Harstarka (2004) pada industri keuangan mikro di Eropa, Burlaka (2006) pada industri perbankan di Ukraina, Kajola (2008) pada perusahaan yang listed di Nigeria, Kirkpatrick (2009) di Negara OECD setelah krisis keuangan, Adams dan Mehran (2011) pada industri perbankan US, Boyle (2012) di New Zealand, Lukviarman (2004, 2005) di Indonesia, Ramadhani dan Lukviarman (2009) di Indonesia, Kharis dan Suhardjanto (2012) di Indonesia, Endraswati, Suhardjanto dan Krismiaji (2014) di perbankan Indonesia.

Namun, penelitian dan kajian tentang corporate governance dalam Islam, sepengetahuan penulis, masih jarang dilakukan dan masih terus dilakukan eksplorasi tentang konsep-konsepnya (Chapra dan Ahmed, 2002; Choudury dan Haque, 2006; Lewis, 2006; Tapanjeh, 2008; Hasan, 2008; Bahati dan Bahati, 2009). Tulisan ini masih merupakan preliminary concept yang perlu ditindaklanjuti dengan eksekusi penelitian selayaknya corporate governance dengan konsep konvensional. Perbedaan artikel ini dengan artikel yang sudah ada tentang Islamic Corporate Governance adalah artikel ini memberikan mapping artikel yang sudah ada dan indikator Islamic Corporate Governance dengan empat sifat kepemimpinan Rasul yang dapat diaplikasikan untuk penelitian yang akan datang. 


\section{Definisi corporate governance dalam Islam}

Menurut Najmudin (2011) corporate governance dalam Islam adalah sistem yang mengarahkan dan mengendalikan perusahaan untuk memenuhi tujuan perusahaan dengan melindungi kepentingan dan hak semua stakeholder dengan menggunakan konsep dasar pengambilan keputusan berdasarkan epistemologi sosial-ilmiah Islam yang didasarkan pada ketauhidan Allah.

Menurut Bhatti dan Bhatti (2009) Islamic Corporate Governance mempertimbangkan efek hukum syariah dan prinsip ekonomi dan keuangan Islam pada praktek dan kebijakan, misalnya pada lembaga zakat, pelarangan spekulasi, dan pengembangan sistem ekonomi yang didasarkan pada bagi hasil. Pengambilan keputusan yang dilakukan melebihi konteks corporate governance konvensional yang mencakup pemegang saham, supplier, kreditur, konsumen, pesaing, dan karyawan (Lewis, 2006). Tujuan utama Islamic Corporate Governance adalah Maqasid Shariah yang merujuk pada kesejahteraan masyarakat (Hasan, 2008).

Perbankan syariah, lembaga keuangan mikro syariah, dan lembaga keuangan syariah nonbank merupakan contoh perusahaan yang mengaplikasikan konsep corporate governance dalam Islam. Hal yang membedakan corporate governance di perbankan syariah dibandingkan dengan perbankan konvensional adalah hadirnya Dewan Pengawas Syariah dalam struktur corporate governance-nya. Menurut PBI No. 11/33/2009 tentang pelaksanaan good corporate governance bagi Bank Umum Syariah dan Unit Usaha Syariah, Dewan Pengawas Syariah memiliki fungsi untuk memberikan nasihat dan saran kepada direksi serta mengawasi kegiatan bank agar sesuai dengan prinsip syariah. Hal ini tercantum pada pasal 1 (1).

Corporate governance tidak hanya berkaitan dengan struktur, tetapi juga dengan mekanisme corporate governance (Lukviarman, 2004). Mekanisme yang membedakan antara perusahaan konvensional dan syariah adalah mekanisme pengambilan keputusan. Pengambilan keputusan dalam perusahaan syariah didasarkan pada hukum Islam yaitu Al Qur'an dan Sunah Rasullullah saw, sedangkan perusahaan dengan corporate governance konvensional lebih menekankan kesesuaian dengan undang-undang dan peraturan pemerintah. 


\section{Prinsip-prinsip corporate governance dalam Islam}

Untuk menyampaikan wahyu Allah swt pada umatnya, para rasul dibekali dengan empat sifat wajib yaitu shiddiq, amanah, tabligh, dan Fathanah. Keempat sifat wajib rasul tersebut menjadi sifat kepemimpinan dalam Islam (Arief, 2014). Karena itu pula, empat sifat wajib rasul tersebut dijabarkan dalam aplikasi Islamic Corporate Governance yang didasarkan pada hukum Al Qur'an dan Hadist. Prinsip-prinsip corporate governance dalam Islam meliputi:

\section{Shiddiq}

Shiddiq berarti jujur artinya apa yang disampaikan adalah keadaan yang sebenarnya. Orang dengan karakteristik seperti ini merasa bahwa Allah selalu ada untuk mengawasi perilakunya, sehingga ia menjadi takut untuk melakukan dusta. Kejujuran merupakan salah satu pilar utama dalam corporate governance secara Islam. Beberapa dasar hukum tentang sifat shiddiq ini adalah:

"Hai orang-orang yang beriman, bertakwalah kepada Allah dan hendaklah kamu bersama orang-orang yang benar" (QS AITaubah:[9]: 119).

Selain itu, dalam sebuah hadis Rasulullah Saw bersabda:

"Hendaklah kalian jujur (benar) karena kejujuran mengantarkan kepada kebaikan. Dan kebaikan akan mengantarkan ke dalam surga. Seseorang yang selalu berusaha untuk jujur akan dicatat oleh Allah sebagai orang jujur. Dan jauhilah oleh kamu sekalian dusta (kidzib), karena dusta itu akan mengantarkan kepada kejahatan. Dan kejahatan akan mengantarkan ke dalam neraka. Seseorang yang selalu berdusta akan dicatat oleh Allah sebagai pendusta" (HR AI-Bukhari).

Corporate governance dalam Islam menekankan kejujuran dalam ucapan dan tindakan yang merupakan satu kesatuan. Tidak ada lagi korupsi apabila sifat shiddiq ini dimiliki dan diaplikasikan. Perusahaan akan berkembang lebih baik karena bisnis menjadi lebih bersih, fair, tidak ada penipuan serta kedzaliman. 
Beberapa perusahaan menggunakan shiddiq sebagai salah satu budaya perusahaan seperti Bank Victoria Syariah (Annual Report, 2011). Dalam konteks corporate governance secara umum, shiddiq dapat dikaitkan dengan prinsip transparansi dan amanah (OECD, 1999). Penelitian tentang transparansi telah dilakukan dalam konteks penelitian corporate governance konvensional oleh Ormrod dan Cleaver (1993) di UK, Keasey dan Wright (1993), Bushman dan Smith (2003) di US, Bannister dan Newman (2003), Archer (2007), Parker (2007), Li, Pike, dan Haniffa (2008) di UK, Lewis (2009) di US, Suhardjanto, Dewi, Rahmawati (2012) di Indonesia, Kharis dan Suhardjanto (2012) di Indonesia.

\section{Amanah}

Amanah berarti dapat dipercaya, tidak ingkar janji dan bertanggung jawab. Apa yang telah disepakati akan ditunaikan dengan sebaik-baiknya. Sikap ini memberikan trustworthiness (kepercayaan) dari pihak eksternal dan internal perusahaan. Kepercayaan pihak lain terhadap perusahaan memberikan implikasi seperti investasi, pembiayaan, dan image atau reputasi. Dasar hukum sifat amanah yang digunakan dalam corporate governance secara Islam adalah: "Dan orang-orang yang memelihara amanat-amanat dan janji janjinya” (QS AI-Mu'minun [ 23]: 8).

Selain itu, Allah Swt. berfirman:

"Sesungguhnya Allah menyuruh kamu menyampaikan amanat kepada yang berhak menerimanya dan (menyuruh kamu) apabila menetapkan hukum di antara manusia supaya kamu menetapkan dengan adil. Sesungguhnya Allah memberikan pengajaran sebaik-baiknya kepadamu. Sesungguhnya Allah adalah Maha Mendengar lagi Maha Melihat" (QS An Nisa 58)

Amanah berarti pula menjaga komitmen. Menciptakan komitmen lebih mudah daripada memeliharanya, karena komitmen membutuhkan niat tulus dan integritas serta loyalitas. Sikap amanah akan mendatangkan rezeki karena stakeholder menjadi percaya pada perusahaan.

Beberapa perusahaan menggunakan amanah sebagai salah satu budaya perusahaan seperti Bank Mega Syariah, Bank Syariah Bukopin, Bank 
Victoria Syariah, dan BNI Syariah (Annual Report, 2011). Dalam konteks corporate governance secara umum, amanah dapat dikaitkan dengan prinsip transparansi dan akuntabilitas (OECD, 1999). Penelitian tentang transparansi dan akuntabilitas dalam konteks corporate governance konvensional diteliti oleh Uzliawati (2015), Supriyono, Mustaqim, dan Suhardjanto (2014).

\section{Tablig}

Tablig berarti menyampaikan. Hal ini berarti menyampaikan kebenaran. Kalau dahulu rasul menyampaikan wahyu Allah swt, maka sekarang umat muslim wajib pula menyampaikan kebenaran. Allah swt memerintahkan menegakkan yang makruf dan mencegah yang munkar serta berlaku bijaksana pada kedua urusan tersebut. Hal ini tercantum dalam QS Ali Imran (110) dan QS An Nahl (90). Allah swt berfirman:"Kamu adalah umat yang terbaik yang dilahirkan untuk manusia, menyuruh kepada yang ma'ruf dan mencegah dari yang munkar, dan beriman kepada Allah.” (QS Ali Imran: 110)

Dengan sikap tablig diharapkan dapat menjadi pimpinan yang bijaksana sehingga mengerti mana yang benar dan mana yang salah sehingga dapat mengajak yang lain ke arah kebenaran. Allah swt berfirman,

"Hai orang-orang yang beriman, bertakwalah kamu kepada Allah dan katakanlah perkataan yang benar (qaulan sadidan), niscaya Allah memperbaiki bagimu amal-amalmu dan mengampuni bagimu dosadosamu. Dan barang siapa mentaati Allah dan Rasul-Nya, maka sesungguhnya ia telah mendapatkan kemenangan yanq besar" (QS AI-Ahzab [33] 70-71).

Allah swt berfirman,

"Kami tidak mengutus seorang rasul pun, melainkan dengan bahasa kaumnya, supaya dia dapat memberi penjelasan dengan terang kepada mereka "“ (QS Ibrahim [14]: 4).

Dalam konteks corporate governance secara umum, tablig dapat dikaitkan dengan prinsip responsibility (OECD, 1999). Penelitian tentang responsibility dalam konteks corporate governance konvensional diteliti oleh Adam dan Ferreira (2009) di US kaitannya dengan meeting CEO, Endraswati, 
Krismiaji dan Suhardjanto (2014) di Indonesia tentang tanggung jawab komisaris dalam penentuan remunerasi.

\section{Fathanah}

Fathanah berarti cerdas. Penelitian-penelitian tentang corporate governance yang dikaitkan dengan kecerdasan atau kompetensi dapat dilihat dari prestasi kerja, pengalaman, pendidikan, masa kerja, dan pelatihan yang diikuti. Perusahaan membutuhkan orang yang cerdas sebagai SDM-nya. Dengan kecerdasan yang dimiliki, maka permasalahan perusahaan akan teratasi, sehingga kinerja dan nilai perusahaan akan meningkat.

Pada masa rasul, kecerdasan diperlukan untuk menyampaikan wahyu Allah swt kepada umatnya. Tidak semua umat menerima apa yang diajarkan dan disampaikan rasul. Karena itulah, diperlukan kecerdasan untuk menghadapi kaum tersebut. Hal ini tercantum dalam QS. Al An'am (83) yang artinya: "Dan itulah hujah Kami yang Kami berikan kepada Ibrahim untuk menghadapi kaumnya"

Kecerdasan yang diberikan Allah swt kepada umatnya harus dimanfaatkan untuk kesejahteraan bersama. Allah swt tidak menyukai kaum yang malas dan tidak mau berpikir dengan menggunakan akalnya.

Allah SWT. berfirman:

"Dan Dialah Tuhan yang membentangkan bumi dan menjadikan gunung-gunung dan sungai-sunqai padanya. Dan menjadikan padanya semua buah-buahan berpasang-pasangan. Allah menutupkan malam kepada siang. Sesungguhnya pada yang demikian itu terdapat tanda-tanda (kebesaran Allah) bagi kaum yang memikirkan" (QS AIRa'd [13]: 3).

Sifat fathanah akan mendukung ketiga sifat lain dalam Islamic Corporate Governance. Karena dengan sifat fathanah, maka pemimpin akan menjadi bijaksana, terbuka wawasan berpikirnya, mampu menghadapi perubahan jaman, mampu menggunakan peluang untuk kemajuan perusahaan, mampu menghadapi tantangan, memperbaiki kelemahan dan mempertahankan kelebihan yang dimiliki perusahaan. Kecerdasan yang dimaksud meliputi kecerdasan intelektual dan spiritual. 
Dalam konteks corporate governance secara umum, fathanah dapat dikaitkan dengan prinsip responsibility (OECD, 1999). Beberapa penelitian dilakukan dalam konteks corporate governance konvensional oleh Brick (2006), Bachan (2008), Reeb dan Zhao (2009), Beasley dan Salterio (2001), Adams dan Ferreira (2009).

Tabel 1 di bawah ini menjelaskan tentang aplikasi empat pilar sifat kepemimpinan Islam dalam Islamic Corporate Governance. Kolom indikator merupakan pengukuran yang dapat dikembangkan pada Islamic Corporate Governance yang sebelumnya telah digunakan dalam Corporate Governance konvensional.

\section{Tabel 1}

Aplikasi Empat Pilar Sifat Kepemimpinan Islam dalam Islamic Corporate Governance

\begin{tabular}{|c|c|c|}
\hline $\begin{array}{c}\text { Sifat } \\
\text { Shiddiq dan } \\
\text { Amanah }\end{array}$ & Aplikasi & $\begin{array}{c}\text { Indikator dan Peneliti pada } \\
\text { CG konvensional }\end{array}$ \\
\hline Strukt ur & $\begin{array}{l}\checkmark \text { Orang-orang yang berada pada } \\
\text { posisi direksi, komisaris, dan } \\
\text { Dewan Pengawas Syariah } \\
\text { adalah orang yang jujur dan } \\
\text { terkenal kredibilitasnya } \\
\checkmark \quad \text { Komisaris Independen adalah } \\
\text { orang yang benar-benar } \\
\text { independen pada kepentingan } \\
\text { perusahaan (pure independent } \\
\text { dan bukan independent in fact) } \\
\checkmark \quad \begin{array}{l}\text { Auditor internal perusahaan } \\
\text { adalah pihak yang mampu } \\
\text { melakukan audit perusahaan } \\
\text { dengan jujur } \\
\checkmark \\
\text { Auditor eksternal perusahaan } \\
\text { adalah auditor yang sudah } \\
\text { memiliki reputasi terpercaya } \\
\text { dan independen }\end{array} \\
\end{array}$ & $\begin{array}{ll} & \text { Jumlah Direksi, } \\
& \text { Komisaris, Dewan } \\
& \text { Pengawas Syariah } \\
& \text { (Coles, 2008) } \\
\checkmark & \text { Proporsi anggota } \\
& \text { independen (Endraswati } \\
& \text { et al., 2014) } \\
\checkmark & \text { Tingkat reputasi } \\
& \text { (Rubin, 2011) } \\
\checkmark & \text { Tingkat independensi } \\
& \text { Auditor dan Komisaris } \\
& \text { Independen (Felo dan } \\
& \text { Soleri, 2009) } \\
\checkmark & \text { Tingkat kehadiran } \\
& \text { dalam meeting (Brick } \\
\text { dan Chidambaran, } & \text { 2007) } \\
\checkmark & \text { Agenda meeting dan }\end{array}$ \\
\hline Mekanisme & $\begin{array}{ll}\checkmark & \text { Remunerasi yang diberikan } \\
\text { merupakan hasil } \\
\text { prestasi/kinerja yang } \\
\text { sebenarnya } \\
\checkmark \\
\text { Meeting yang dilakukan oleh } \\
\text { direksi, komisaris, dan Dewan } \\
\text { Pengawas Syariah memberikan } \\
\text { output yang signifikan pada } \\
\end{array}$ & $\begin{aligned} & \text { Kontribusi peserta } \\
& \text { meeting (Davies, 2000) } \\
& \checkmark \text { Remunerasi } \\
& \text { (Endraswati et al., } \\
& \text { 2014) } \\
& \checkmark \text { Prosentase kepemilikan } \\
& \text { saham direksi, } \\
& \text { komisaris, dan Dewan } \\
&\end{aligned}$ \\
\hline
\end{tabular}




\begin{tabular}{|c|c|c|c|c|}
\hline & $\checkmark$ & $\begin{array}{l}\text { perusahaan. Artinya pimpinan } \\
\text { tidak hanya sekedar datang } \\
\text { meeting, tetapi masing-masing } \\
\text { memiliki kontribusi yang } \\
\text { penting pada meeting } \\
\text { Agenda meeting diungkapkan } \\
\text { dengan jujur } \\
\quad \text { Kepemilikan saham } \\
\quad \text { perusahaan }\end{array}$ & $\begin{array}{l}\checkmark \\
\checkmark \\
\checkmark \\
\checkmark\end{array}$ & $\begin{array}{l}\text { Pengawas Syariah } \\
\text { (Endraswati et al., } \\
\text { 2014). } \\
\text { Prosentase anggota } \\
\text { keluarga dalam jajaran } \\
\text { Direksi, Komisaris, dan } \\
\text { Dewan Pengawas } \\
\text { Syariah (Maury, 2006) } \\
\text { Prosentase kepemilikan } \\
\text { mayoritas (Surifah, } \\
\text { 2011) } \\
\text { Prosentase kepemilikan } \\
\text { minoritas (La Porta, } \\
\text { 1999) } \\
\text { Prosentase kepemilikan } \\
\text { institusi (Cornett, 2007) }\end{array}$ \\
\hline \multicolumn{5}{|r|}{ och } \\
\hline & $\checkmark$ & $\begin{array}{l}\text { Direksi menyampaikan } \\
\text { informasi yang akurat dan } \\
\text { terpercaya tentang perusahaan } \\
\text { pada publik melalui web atau } \\
\text { laporan tahunan perusahaan } \\
\text { Direksi membuat laporan } \\
\text { keuangan yang jujur dan } \\
\text { disampaikan terutama unt uk } \\
\text { kepentingan pemegang saham } \\
\text { dan stakeholder pada umumnya } \\
\text { Tidak adanya insider } \\
\text { information dalam perusahaan } \\
\text { karena informasi diungkapkan }\end{array}$ & $\begin{array}{l}\checkmark \\
\checkmark \\
\end{array}$ & $\begin{array}{l}\text { Tingkat pengungkapan } \\
\text { informasi (disclosure) } \\
\text { perusahaan } \\
\text { Berdasarkan ketaatan } \\
\text { pada regulasi dibagi } \\
\text { menjadi mandatory } \\
\text { disclosure (Kharis dan } \\
\text { Suhardjanto, 2012; } \\
\text { Supriyono et al., 2014) } \\
\text { dan voluntary disclosure } \\
\text { (Uzliawati et al., 2014) } \\
\text { Berdasarkan jenis } \\
\text { disclosure seperti social } \\
\text { disclosure, intellectual } \\
\text { capital disclosure, } \\
\text { financial disclosure, risk } \\
\text { disclosure, } \\
\text { environmental } \\
\text { disclosure, dan } \\
\text { remuneration disclosure } \\
\text { (Suhardjanto et al., } \\
\text { 2012, Uzliawati, 2015) }\end{array}$ \\
\hline
\end{tabular}




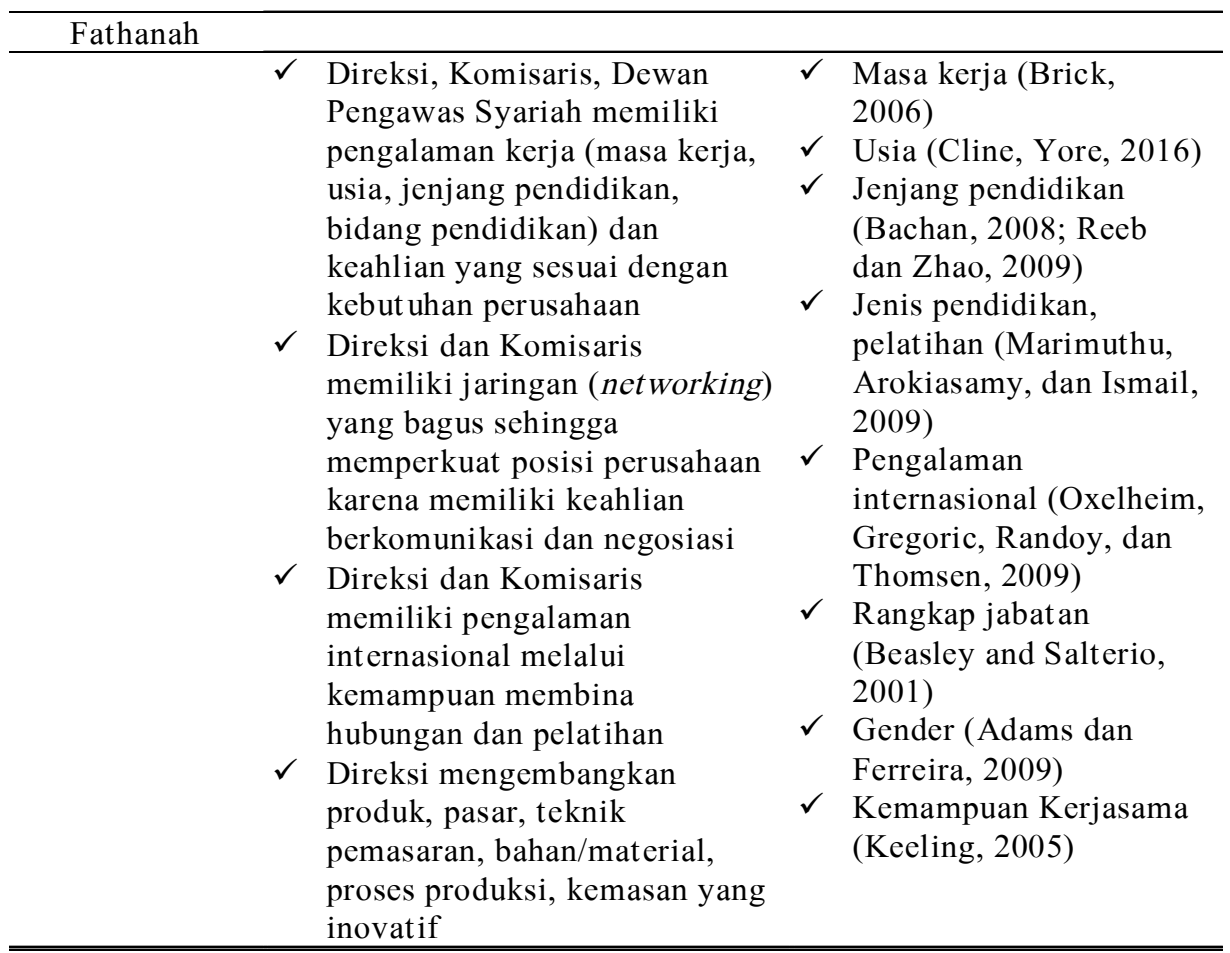

Beberapa peneliti telah mencoba untuk meletakkan fondasi konseptual Islamic Corporate Governance. Beberapa peneliti tersebut ada pada Tabel 2 di bawah ini.

Tabel 2

Mapping Penelitian tentang Islamic Corporate Governance

\begin{tabular}{|c|c|c|c|c|c|}
\hline No & Peneliti & Lokasi & Topik & Metode & Hasil \\
\hline 1 & $\begin{array}{l}\text { Chapra dan } \\
\text { Ahmed (2002) }\end{array}$ & $\begin{array}{l}\text { Bahrain, } \\
\text { Kuwait, dan } \\
\text { Uni Emirat } \\
\text { Arab }\end{array}$ & $\begin{array}{l}\text { CG pada } \\
\text { Lembaga } \\
\text { Keuangan } \\
\text { Islam }\end{array}$ & Survey & $\begin{array}{l}\text { Perlu adanya perbaikan } \\
\text { komposisi BOD, } \\
\text { hukum, dan } \\
\text { perlindungan } \\
\text { kepentingan stakeholder } \\
\text { terutama pemegang } \\
\text { deposito. }\end{array}$ \\
\hline 2 & Lewis (2005) & - & Islamic $C G$ & $\begin{array}{l}\text { Analisis } \\
\text { Konseptual }\end{array}$ & $\begin{array}{l}\text { Beberapa pendekatan } \\
\text { alternatif dalam Islamic } \\
\text { CG yaitu shuratic } \\
\text { decision making, } \\
\text { religious audit, dan } \\
\text { shariah supervision } \\
\text { process }\end{array}$ \\
\hline 3 & $\begin{array}{l}\text { Choudhury dan } \\
\text { Haque (2006) }\end{array}$ & - & Islamic $C G$ & $\begin{array}{l}\text { Analisis } \\
\text { Konseptual }\end{array}$ & $\begin{array}{l}\text { Konseptual Framework } \\
\text { Islamic CG }\end{array}$ \\
\hline
\end{tabular}




\begin{tabular}{|c|c|c|c|c|c|}
\hline 4 & $\begin{array}{l}\text { Dar dan } \\
\text { Presley (2000) }\end{array}$ & - & $\begin{array}{l}\text { Profit dan } \\
\text { Loss Sharing } \\
\text { pada } \\
\text { Perbankan } \\
\text { Islam: } \\
\text { Ketidakseim } \\
\text { bangan } \\
\text { manajemen } \\
\text { dan control }\end{array}$ & $\begin{array}{l}\text { Analisis } \\
\text { Konseptual }\end{array}$ & $\begin{array}{l}\text { Ketidakseimbangan } \\
\text { manajemen dan kontrol } \\
\text { menyebabkan } \\
\text { kurangnya praktik PLS } \\
\text { di perbankan islam. Hal } \\
\text { ini dimungkinkan } \\
\text { munculnya agency } \\
\text { problem }\end{array}$ \\
\hline 5 & Munid (2007) & - & $\begin{array}{l}\text { Corporate } \\
\text { Governance } \\
\text { in Islamic } \\
\text { Perspective }\end{array}$ & $\begin{array}{l}\text { Analisis } \\
\text { Konseptual }\end{array}$ & $\begin{array}{l}\text { Islamic Corporate } \\
\text { Governance dikaitkan } \\
\text { dengan prinsip utama } \\
\text { CG secara umum yaitu } \\
\text { akuntabilitas, } \\
\text { transparansi, tanggung } \\
\text { jawab, dan }\end{array}$ \\
\hline 6 & $\begin{array}{l}\text { Safieddine } \\
(2009)\end{array}$ & $\begin{array}{l}\text { 40 lembaga } \\
\text { keuangan di } \\
\text { Saudi } \\
\text { Arabia, } \\
\text { Kuwait, } \\
\text { Qatar, } \\
\text { Bahrain, dan } \\
\text { Uni Emirat } \\
\text { Arab }\end{array}$ & $\begin{array}{l}\text { Institusi } \\
\text { Keuangan } \\
\text { Islam dan } \\
\text { Corporate } \\
\text { Governance } \\
\text { kaitannya } \\
\text { dengan } \\
\text { Agency } \\
\text { Theory }\end{array}$ & Survey & $\begin{array}{l}\text { Governance dikaitkan } \\
\text { dengan audit, kontrol, } \\
\text { dan transparansi. } \\
\text { Shariah compliance dan } \\
\text { mekanisme } \\
\text { perlindungan investor } \\
\text { sebagai trade off. }\end{array}$ \\
\hline 7 & $\begin{array}{l}\text { Abdullah dan } \\
\text { Valentine } \\
(2009)\end{array}$ & Global & $\begin{array}{l}\text { Corporate } \\
\text { Governance } \\
\text { dan Etika }\end{array}$ & $\begin{array}{l}\text { Analisis } \\
\text { Teori CG }\end{array}$ & $\begin{array}{l}\text { Konsep teori Corporate } \\
\text { Governance }\end{array}$ \\
\hline 8 & Hasan (2009) & - & $\begin{array}{l}\text { Corporate } \\
\text { Governance } \\
\text { konsep } \\
\text { Western dan } \\
\text { Islam }\end{array}$ & $\begin{array}{l}\text { Analisis } \\
\text { konseptual }\end{array}$ & $\begin{array}{l}\text { Perbandingan konsep } \\
\text { teori Islamic Corporate } \\
\text { Governance dan } \\
\text { Western Corporate } \\
\text { Governance }\end{array}$ \\
\hline 9 & Kasri (2009) & - & $\begin{array}{l}\text { Corporate } \\
\text { Governance: } \\
\text { Islam vs } \\
\text { Konvensiona } \\
1\end{array}$ & $\begin{array}{l}\text { Analisis } \\
\text { Konseptual }\end{array}$ & $\begin{array}{l}\text { Perbedaan mencakup } \\
\text { filosofi, tipe kontrak, } \\
\text { struktur, mekanisme, } \\
\text { dan alat Corporate } \\
\text { Governance yang } \\
\text { efektif }\end{array}$ \\
\hline 10 & $\begin{array}{l}\text { Tapanjeh } \\
(2009)\end{array}$ & - & $\begin{array}{l}\text { Islamic } \\
\text { Corporate } \\
\text { Governance } \\
\text { dengan } \\
\text { analisis } \\
\text { perbandingan } \\
\text { prinsip } \\
\text { OECD }\end{array}$ & $\begin{array}{l}\text { Analisis } \\
\text { Konseptual }\end{array}$ & $\begin{array}{l}\text { Ada enam perbedaan } \\
\text { prinsip OECD dengan } \\
\text { perspektif Islam yang } \\
\text { lebih luas }\end{array}$ \\
\hline 11 & $\begin{array}{l}\text { Farook dan } \\
\text { Faroq (2013) }\end{array}$ & - & $\begin{array}{l}\text { Shariah } \\
\text { Governance: } \\
\text { Keahlian dan } \\
\text { Profesionalit } \\
\text { as }\end{array}$ & $\begin{array}{l}\text { Analisis } \\
\text { Konseptual }\end{array}$ & $\begin{array}{l}\text { Kekurangan praktisi } \\
\text { pada industri keuangan } \\
\text { islam diatasi melalui } \\
\text { pendidikan, kurikulum, } \\
\text { dan lembaga sertifikasi }\end{array}$ \\
\hline 12 & $\begin{array}{l}\text { Suleiman } \\
(2009)\end{array}$ & - & $\begin{array}{l}\text { Corporate } \\
\text { Governance } \\
\text { pada Bank } \\
\text { Islam }\end{array}$ & $\begin{array}{l}\text { Analisis } \\
\text { Konseptual }\end{array}$ & $\begin{array}{l}\text { Corporate Governance } \\
\text { berdasarkan Quran, } \\
\text { adanya Shirkah dan } \\
\text { Mudharabah }\end{array}$ \\
\hline
\end{tabular}

Sumber: Berbagai Jurnal 
Berdasarkan tabel 2 tentang perkembangan penelitian Islamic Corporate Governance di atas, dapat dinyatakan bahwa penelitian tentang Islamic Corporate Governance yang ada baru pada tahap pengembangan konseptual. Beberapa peneliti yang ada menggunakan Bank Syariah atau Lembaga Keuangan Syariah sebagai obyek penelitiannya dengan metode survey, namun eksekusi penelitian dengan metode kuantitatif masih sangat jarang dilakukan.

\section{Perbandingan corporate governance dalam Islam dengan corporate governance konvensional}

Prinsip-prinsip Corporate Governance konvensional sebenarnya telah tercakup dalam prinsip-prinsip Islamic Corporate Governance. Transparansi merujuk pada shiddiq, akuntabilitas merujuk pada shiddiq dan amanah, responsibility merujuk pada amanah, tablig, dan fathanah, fairness merujuk pada shiddiq dan amanah. Hal yang perlu digaris bawahi adalah meskipun prinsip-prinsip Corporate Governance konvensional tercakup dalam prinsipprinsip Islamic Corporate Governance bukan berarti keduanya adalah hal yang sama. Karena dasar hukum yang digunakan berbeda maka pelaksanaan dan aplikasinyapun akan berbeda. Berdasarkan perbandingan prinsip-prinsip tersebut, prinsip-prinsip yang digunakan dalam Islamic Corporate Governance lebih lengkap apabila dibandingkan dengan Corporate Governance konvensional. 
Tabel 3

Perbedaan Islamic Corporate Governance dan Corporate Governance Konvensional

\begin{tabular}{|c|c|c|}
\hline & CG dalam Islam & CG Konvensional \\
\hline Prinsip & $\begin{array}{l}\text { Shiddiq, Amanah, Tablig, } \\
\text { Fathanah }\end{array}$ & $\begin{array}{l}\text { Transparansi, Akuntabilitas, } \\
\text { Responsibility, Fairness (OECD, } \\
\text { 1999) }\end{array}$ \\
\hline Dasar Hukum & Al Quran dan Hadist & $\begin{array}{l}\text { UU tentang PT, Peraturan } \\
\text { Bapepam, Peraturan BI, Surat } \\
\text { Edaran BI }\end{array}$ \\
\hline Struktur & $\begin{array}{l}\text { Rapat Umum Pemegang Saham, } \\
\text { Dewan komisaris, Direksi, Dewan } \\
\text { Pengawas Syariah (PBI tahun } \\
\text { 2009) }\end{array}$ & $\begin{array}{l}\text { Rapat Umum Pemegang Saham, } \\
\text { Dewan komisaris dan Direksi } \\
\text { (PBI tahun 2007) }\end{array}$ \\
\hline Mekanisme & $\begin{array}{l}\text { Kontrak kerjasama dan } \\
\text { meeting/musyawarah (Najmuddin, } \\
\text { 2011) }\end{array}$ & $\begin{array}{l}\text { Internal dan eksternal } \\
\text { (Lukviarman, 2004) }\end{array}$ \\
\hline Teori & $\begin{array}{l}\text { Stakeholder Theory (Freeman, } \\
\text { 1984) } \\
\text { Ethics Theory (Crane dan Matten, } \\
\text { 2007) }\end{array}$ & $\begin{array}{l}\text { Agency Theory (Jensen dan } \\
\text { Meckling, 1976), Stakeholder } \\
\text { Theory (Freeman, 1984), } \\
\text { Stewardship Theory (Davis, } \\
\text { Schoorman, dan Donaldson, } \\
\text { 1997), Resource Dependence } \\
\text { Theory (Hillman, Canella, dan } \\
\text { Paetzold (2000), Political } \\
\text { Theory (Pound, 1993), } \\
\text { Transaction Cost Theory (Cyert } \\
\text { dan March, 1963) }\end{array}$ \\
\hline $\begin{array}{l}\text { Efek } \\
\text { Pengambilan } \\
\text { Keputusan }\end{array}$ & Stakeholder (Lewis, 2006) & $\begin{array}{l}\text { Shareholder (Bhatti dan Bhatti, } \\
\text { 2009) }\end{array}$ \\
\hline Tujuan & Maqasid Shariah (Hasan, 2008) & $\begin{array}{l}\text { Memperhatikan kepentingan } \\
\text { pemegang saham (Bhatti dan } \\
\text { Bhatti, 2009) }\end{array}$ \\
\hline
\end{tabular}

Sumber: Jurnal Diolah

Corporate Governance dalam konteks konvensional seringkali dikaitkan dengan capaian kinerja dan nilai perusahaan (Daucaligious, Askary, dan Haman, 2006; Rajgopal, Shevlin, dan Zamora, 2006; Windsor dan Cybinski, 2009), pengungkapan informasi (Kharis dan Suhardjanto, 2012; Uzliawati, Suhardjanto, dan Jati, 2014), cost of capital (Suchard, Pham, dan Zein, 2012), dan remunerasi (Endraswati et. al., 2014). Penelitian tentang Islamic Corporate Governance dengan menggunakan empat sifat kepemimpinan Rasul, sepengetahuan penulis sampai saat ini belum ada yang mengkaitkan dengan hal-hal tersebut. 


\section{Penut up}

Konsep corporate governance dalam Islam sebenarnya telah ada dan sudah dilakukan jauh sebelum konsep corporate governance konvensional yaitu sejak jaman rasul penyampai wahyu Allah swt. Prinsip-prinsip shiddiq, amanah, tabligh dan fathanah menjadi prinsip Islamic Corporate Governance yang dapat diaplikasikan dan diteliti terutama pada perusahaan di Indonesia.

\section{Daftar Pustaka}

Abdullah, Haslinda \& Benedict Valentine. 2009. Fundamental and Ethics Theories of Corporate Governance, Middle Eastern Finance and Economics. 4: 88-97.

Adams, Renee B \& Hamid Mehran. 2008. Corporate Performance, Board Structure, and Their Determinants in the Banking Industry. Federal Reserve Bank of New York Staff Report. 330: 1-49.

Adams, Renee B \& Daniel Ferreira. 2009. Women in the Boardroom and Their Impact on Governance and Performance, Journal of Financial Economics. 94: 291-309.

Archer, Simon. 2007. Financial and External Reporting Research: The Broadening Corporate Governance Challenge, Accounting and Business Research. Vol. 37 (1): 55-58.

Arief, Zay. 2014. Karakteristik Kepemimpinan Islam Telaah Sifat Wajib Rasul. www.academia.edu

Bachan, Ray. 2008. On the Determinants of Pay of CEOs in UK Public Sector Higher Education Institutions, IZA Discussion Paper. No. 3858:136

Bannister, James W \& Harry A Newman. 2003. Analysis of Corporate Disclosures on Relative Performance Evaluation, Accounting Horizonz. Vol. 17 (3): 235-246.

Beasley, M. S \& Salterio, S. E. 2001. The relationship between board characteristics and voluntary improvements in audit committee composition and experience. Contemporary Accounting Research. 18(4): 539 - 570.

Bhatti, Maria \& Ishaq Bhatti. 2009. Development in Legal Issue of Corporate Governance in Islamic Finance, Journal of Economic \& Administrative Sciences. Vol 25 (1): 67-91.

Brick, I. E; O. Palmon \& J. K. Wald. 2006. CEO Compensation, Director Compensation, and Firm Performance : Evidence from Cronysm, 
Journal of Corporate Finance. 12: 403-423.

Brick E, Ivan \& Chidambaran N. K. 2007. Board Meeting, Committee Structure, and Firm Performance, http://papers.ssrn.com diunduh 30 Maret 2011

Boyle, Glenn \& Helen Roberts. 2012. CEO Presence on the Compensation Committee: A Puzzle, Working Paper. Otago University.

Burlaka, Maksym V. 2006. Bank Corporate Governance: The Emerging Ukrainain Market Compared to International Best Practice, Fordham Journal of Corporate \& Financial Law. Vol 11 (4): 851891.

Bushman, Robert M \& Abbie J. Smith. 2003. Transparency, Financial Accounting Information, and Corporate Governance, FRBNY Economic Policy Review. April.

Crane, A. \& D. Matten. 2007. Business Ethics. Oxford University Press.

Chapra, M. Umer \& Habib Ahmed. 2002. Corporate Governance in Islamic Financial Institutions, Occasional Paper. Islamic Research and Training Institute Islamic Development Bank.

Choudury, M. A \& M. Z. Haque. 2004. An Advanced Exposition of Islamic Economics and Finance, New York. Edward Mellen Press.

Cline, Brandon \& Adam S Yore. 2016. Silverback CEOs: Age, Experience and Firm Value, Journal of Empirical Finance. Vol. 35: 169-188.

Coles, J. L. Daniel \& Naveen L. 2008. Board: Does One Size Fit All?, Journal of Financial Economics. 87 (2): 329-356.

Cornett, Marcia Millon. Alan J Marcus. Anthony Sanders \& Hasan Tehranian. 2007. The Impact of Institutional Ownership on Corporate Operating Performance, Journal of Banking and Finance. 31: 1771-1794.

Cyert, R. M. \& J. G. March. 1963. A Behavior Theory of the Firm. New Jersey. Prentice Hall.

Dar, Humayon A \& John R. Presley. 2000. Lack of Profit Sharing in Islamic Banking: Management and Control Imbalances, International Journal of Islamic Financial Services. Vol. 2 (2):1-16.

Daucouliagos, Hristos; Saeed Askari \& Janto Haman. 2006. Directors Remuneration and Performance in Australia Banking, Working Paper, School of Accounting, Economics and Finance, Faculty of Business and Law, Deakin University.

Davies, Paul L. 2000. The Board of Directors: Composition, Structure, Duties and Powers. OECD. Sweden.

Davis, J. H. Schoorman, F. D \& L. Donaldson. 1997. Toward a Stewardship Theory of Management, Academy of Management Review. Vol. 


\section{2: $20-47$.}

Donaldson, Lex \& James H. Davis. 1991. Stewardship Theory or Agency Theory: CEO Governance and Shareholder Returns, Australian Journal of Management. 16 (1): 49-65.

Emmons, William R \& Frank A. Schmid. 1999. Corporate Governance and Firm Performance. Working Paper.

Endraswati, Hikmah. Djoko Suhardjanto \& Krismiaji. 2014. Board of Director and Remuneration in Indonesia Banking, GSTF Journal on Business Review. Vol. 3 (3): 40-45.

Farook, Sayd \& Mohammad Omar Farooq. 2013. Shariah Governance, Expertise, and Profession: Educational Challenges in Islamic Finance, ISRA International Journal of Islamic Finance. Vol. 5 (1): 137-163.

Faqih, Mansyur. 2014. Mengingat Kembali Awal Mula Kasus Bank Century. Diunduh www.republika.co.id.

Freeman, R. E. 1984. Response: Divergence Stakeholder Theory, Academy of Management Review. Vol. 24 (2): 233-236.

Garry. 2012. Worldcom: Kebangkrutan Besar yang Penuh Skandal. Diunduh www.computesta.com

Felo, Andrew \& Steven A. Soleri. 2009. Are all audit committee financial expert created equaly. International Journal of Disclosure and Governance. 6 (2):150-166.

Hafikahadiyanti. 2013. Sejarah Kasus Enron. Diunduh http:// hafikahadiyanti.wordpress.com/2013

Hasan, Zulkifli. 2009. Corporate Governance: Western and Islamic Perspectives, International Review of Business Research Papers. Vol. 5 (1): 277-293.

Hartarska, Valentina. 2004. Governance and Performance of Microfinance Institutions in Central and Eastern Europe and the Newly Independent State. Working Paper. Auburn University.

Hidayat, David. 2015. Kasus Kimia Farma. Diunduh www.Kompasiana.com. Hillman, A. J. A. A. Canella \& R. L. Paetzold. 2000. The Resource Dependency Role of Corporate Directors: Strategic Adaptation of Board Composition in Response to Environmental Change, Journal of Management Studies. Vol. 37 (2): 235-255.

Jensen, M \& W Meckling. 1976. Theory of The Firm: Managerial Behaviour, Agency Costs, and Ownership Structure, Journal of Financial Economics. 3: 305-360.

Kasri, Rahmatina Awaliah. 2009. Corporate Governance: Conventional Vs 
Islamic Perspective, http://www. ssrn.com

Kajola, Sunday O. 2008. Corporate Governance and Firm Performance: The Case of Nigerian Listed Firms, European Journal of Economics, Finance, and Administrative Science. 14: 16-29.

Keasey, Kevin \& Mike Wright. 1993. Issues in Corporate Accountability and Governance: An Editorial, Accounting and Business Research. 23: 291-303.

Keeling, Jennifer J. 2005. Cooperative Performance and Board of Director Characteristics: A Quantitative Investigation, Presented Paper at the American Agriculture Economics Association Annual Meeting. Rhode Island 22-27 Juli 2005

Kharis, Abdul \& Djoko Suhardjanto. 2012. Corporate Governance dan Ketaatan Pengungkapan Wajib pada Badan Usaha Milik Negara, Jurnal Keuangan dan Perbankan. Vol. 16 (1): 37-44.

Kirkpatrick, Grant. 2009. The Corporate Governance Lessons from the Financial Crisis, Financial Market Trends. OECD.

Laporta, Rafael. Florencio Lopez de Silanes \& Andrei Shleifer. 1999. Corporate Ownership Around the World, Journal of Finance. Vol. LIV (2): 471-517

Lewis, Mervyn K. 2005. Islamic Corporate Governance, Review of Islamic Economics. Vol.9 (1): 5-29.

Lewis, Mervyn. 2006. Accountability and Islam, Conference Paper presented at Fourth International Conference on Accounting and Finance in Transition Adelaide, April 10-12, 2006.

Li, Jing. Richard Pike \& Roszaini Haniffa. 2008. Intellectual Capital Disclosure and Corporate Governance Structure in UK Firms, Accounting and Business Research. Vol. 38 (2): 137-159.

Lukviarman, Niki. 2004. Etika Bisnis Tak Berjalan di Indonesia. Ada Apa dalam Corporate Governance, Jurnal Siasat Bisnis. Vol 2 (9): 139156.

Lukviarman, Niki. 2005. Perspektif Shareholding Versus Stakeholding di dalam Memahami Fenomena Corporate Governance, Jurnal Siasat Bisnis. Vol 2 (10): 141-162.

Marimuthu, Maran. Lawrence Arokiasamy \& Maimunah Ismail. 2009. Human Capital Development and Its Impact on Firm Performance: Evidence from Developmental Economics, The Journal of International Social Research. Vol. 2: 265-273.

Maury, Benjamin. 2006. Family Ownership and Firm Performance: Empirical Evidence from Western European Corporation, Journal of Corporate 
Finance. Vol. 12 (2): 321-341.

Munid, Dato' Shahran Laili Haji Abdul. 2007. Corporate Governance in Islamic Perspectives, Paper Presented in $5^{\text {th }}$ International Islamic Finance Conference: Thirty Five Years On The Future of Islamic Finance $3 \& 4$ September 2007. Kuala Lumpur

Najmuddin. 2011. Manajemen Keuangan dan Aktualisasi Syar'iyyah Modern, Andi. Yogyakarta.

Ormrod, P \& K. C. Cleaver. 1993. Financial Reporting and Corporate Accountability, Accounting and Business Research. Vol. 23 (9): 431-439.

Oxelheim, Lars. Aleksandra Gregoric. Trond Randoy \& Steen Thomsen. 2009. Internationalization of the Firm and its Board. Working Paper. Lund Institute of Economic Research.

Parker, Lee. D. 2007. Financial and External Reporting Research: The Broadening Corporate Challenge, Accounting and Business Research. Vol. 37 (1): 39-54.

Peraturan Bank Indonesia No.11/33/2009, Pelaksanaan Corporate Governance Bank Syariah dan Unit Usaha Syariah (UUS). Diunduh: 1 April 2011, dari http://www.bi.go.id

Pound, J. 1993. Proxy Contest and The Efficiency of Shareholder Oversight, Journal of Financial Economics. Vol. 20: 237-265.

Rajgopal, Shivaram, Terry Shevlin \& Valentina Zamora. 2006. CEOs' Outside Employment Opportunities and The Lack of Relative Performance Evaluation in Compensation Contracts, Journal of Finance. Vol. LXI (4):1813-1844.

Ramadhani, Ayu Suci \& Niki Lukviarman. 2009. Perbandingan Analisis Prediksi kebangkrutan Menggunakan Model Altman Pertama, Altman Revisi, dan Altman Modifikasi dengan Ukuran dan Umur Perusahaan sebagai Variabel Penjelas (Studi pada Perusahaan Manufaktur yang Terdaftar di Bursa Efek Indonesia), Jurnal Siasat Bisnis. Vol. 13 (1).

Reeb, David M. \& Wanli Zhao. 2009. Director Capital and Corporate Disclosure quality. Working Paper.

Rubin, Amir \& Dan Segal. 2011. Board Reputation and Financial Reporting Quality. Working Paper diunduh www.insead.edu

Safieddine, Assem. 2009. Islamic Financial Institutions and Corporate Governance: New Insights for Agency Theory, Corporate Governance: An International Review. 17 (2): 142-158.

Shleifer, Andrei \& Robert W. Vishny. 1996. A Survey of Corporate 
Governance, Working Paper. National Bereau of Economics Research.

Suchard, Jo-Ann. Peter K. Pham \& Jason Zein. 2012. Corporate Governance and the Cost of Capital: Evidence from Australian Firms, Journal of Applied Corporate Finance. Vol. 24 (3): 84-93.

Suhardjanto, Djoko. Aryane Dewi. Erna Rahmawati \& Firazonia. 2012. Peran Corporate Governance dalam Praktik Risk Disclosure pada Perbankan Indonesia, Jurnal Akuntansi dan Auditing. Vol. 9 (1): 1-96.

Suleiman, Nasser M. 2009. Corporate Governance in Islamic Banks, Islamic Economics \& Finance Pedia. Diunduh dari www.iefpedia.com

Sullivan, Marry O. 1998. Corporate Governance in Germany Productive and Financial Challenges, The Jerome Levy Economics Institute of Bard College. No. 49: 7-47.

Sumatyo, Riwi. 2003. Kasus Bank Lippo dan Degradasi Kepercayaan Publik.

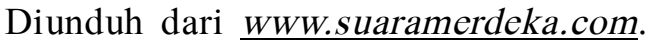

Supriyono, Edy. Achmad Abdul Mustaqim \& Djoko Suhardjanto. 2014. Pengaruh Corporate Governance terhadap Tingkat Kepatuhan Mandatory Disclosure Konfergensi IFRS di Indonesia, Presented Paper SNA 17 Mataram Lombok 24-27 September 2014. Universitas Mataram.

Surifah. 2011. Kepemilikan Ultimat, Tingkat Risiko, Efisiensi, dan Kinerja Industri Perbankan di Indonesia, Jurnal Siasat Bisnis. Vol. 15 (1): 37-53

Tapanjeh, Abdussalam Mahmoud Abu. 2009. Corporate Governance from the Islamic Perspective: A Comparative Analysis with OECD Principles, Critical Perspective on Accounting. 20: 556-567.

Tjager, I.N., A. Alijoyo H.R. Djemat \& B. Sembodo. (2003). Corporate governance: Tantangan dan kesempatan bagi komunitas bisnis Indonesia. Forum Corporate Governance in Indonesia (FCGI).

Uzliawati, Lia. Djoko Suhardjanto \& Kartika Jati. 2014. The Characteristics of Audit Committee and Intellectual Capital Disclosure in Indonesia Banking Industry, GSTF Journal on Business Review. Vol. 3 (2): $18-25$.

Uzliawati, Lia. 2015. Dewan Komisaris dan Intellectual Capital Disclosure pada Perbankan di Indonesia, Jurnal Keuangan dan Perbankan. Vol. 19 (2): 226-234.

Windsor, C. A \& Cybinski. 2009. Size Matters: The Link between CEO Remuneration, Firm Size and Firm Performance Moderated by Remuneration Committee Independence, Discussion Papers Economics, Griffith Business School. 